\title{
Components, structure and fluxes of the microbial food web in a small, stratified lake
}

\author{
Ramon Massana*, Josefina García-Cantizano, Carlos Pedrós-Alió \\ Institut de Ciències del Mar (CSIC), Passeig Joan de Borbó s/n, E-08039 Barcelona, Spain
}

\begin{abstract}
We studied the planktonic community established in Lake Cisó (Girona, Spain) during summer stratification, with the aim of describing the food web of a system as completely as possible. The lake was sampled 19 times during 1990 and 1991 We first determined which populations contributed significantly to total summer biomass. Then, we determined the trophic role of these populations by several independent approaches, and aggregated the community into functional groups. The binary food web obtained indicated that the structure of the food web in Lake Ciso was similar to that found in other systems. Finally, we quantified the trophic fluxes among populations using a simple algorithm which considers the vertical distribution of organisms and the functional responses of the different predators. The trophic food web obtained revealed 2 interesting properties. First, the compartments with larger biomass were relatively stable during stratification and presented slow growth and low predatory losses. Second, there was a very inefficient transfer of organic matter from the lower levels (bacteria, algae and protozoans) to the higher levels (rotifers and zooplankton) of the food web. Both properties could be explained by the fact that most biomass of the system accumulated in the metalimnion, along opposite gradients of oxygen and sulfide, which determined an environment with reduced competition and predation. We postulate that metalimnetic communities above anaerobic hypolimnia can be regarded as sinks of organic matter off the epilimnion.
\end{abstract}

KEY WORDS: Lake Cisó Binary food web - Trophic food web Prey refuge

\section{INTRODUCTION}

The description of the food web of an ecosystem is fundamental to understanding how it functions (Cohen 1989, Pimm et al. 1991). The food web structure determines how the energy and organic matter are channeled and dissipated through the different trophic levels, affecting their biomass and activity. There are several approaches to studying the food web of a particular system, each one requiring more data (Gaedke 1995). In the first approach, the abundance and size of all organisms are determined and the size distribution of the community is obtained. We used this approach with the Lake Cisó (Girona, Spain) community in a previous paper (Gasol et al. 1991b). Addition of the trophic role of each population results in the binary

- Present address: Marine Science Institute, University of California, Santa Barbara, Santa Barbara, California 93106. USA.E-mail: cpedros@cucafera.icm.csic.es food web, which qualitatively shows trophic links among living compartments. Next, fluxes among compartments can be quantified in order to obtain the trophic food web, which describes the flow of matter through the community. Finally, dynamic simulation models can be applied to understand and predict the temporal changes of the ecosystem. Each of these 4 approaches by itself gives interesting information a bout the structure, function and regulation of the food web.

The aim of the present work was to attempt as complete a description of the trophic food web of a pelagic system as possible. For this purpose, we chose Lake Cisó. Lakes are supposed to have a simpler food web than marine systems, since they are closed habitats with clear boundaries (Pomeroy 1991). In addition, Lake Cisó has some interesting advantages that made its study easier than the study of other lakes. It is a well known system (Pedrós-Alió \& Guerrero 1993). In recent years, detailed data on the community composi- 
tion and biomass size distribution (Gasol et al. 1991b, 1992), primary production (García-Cantizano 1992) and bacterial production (Calderón-Paz et al. 1993. García-Cantizano et al. 1994) have been obtained. The community is rather simple, with an absence of fishes and just a few microbial populations composing most of the biomass. Moreover, the community established during spring remains in the metalimnion with minor changes throughout the summer until the fall mixing (Gasol et al. 1992, Massana et al. 1994b), and thus a single food web structure seems to hold throughout stratification. These special characteristics of Lake Cisó have allowed us to study its food web in great detail.

The community found in Lake Cisó is an example of a widespread type of community, found in many other thermally stratified or meromictic lakes in places as distant and with as diverse climates as Japan (Matsuyama \& Shirouzu 1978), Tasmania (Baker et ai. 1985), Spain (Finlay et al. 1991) and Finland (Arvola et al. 1992). These systems are characterized by an extraordinary accumulation of biomass in the metalimnion, at the boundary between oxic and sulfide containing waters. The trophic fate of such biomass is not clear, and whereas some authors have postulated that metalimnetic organisms can represent a significant fraction of the food of some epilimnetic zooplankters (Sorokin 1970, Mazumder \& Dickman 1989), other authors have proposed the contrary, suggesting the metalimnetic biomass to be a sink of carbon from the epilimnion (Fry 1986, Mas et al. 1990). The study of the food web of Lake Cisó can provide the appropriate data set to assess the fate of the metalimnetic biomass in such an ecosystem

\section{MATERIALS AND METHODS}

Lake Cisó. Lake Cisó is a small holomictic lake located in the karstic region of Banyoles (Girona, Spain). The physico-chemical properties of the water column and vertical distributions of organisms have been previously characterized (Gasol et al. 1992, Pedrós-Alió \& Guerrero 1993, Massana \& Pedrós-Alió 1994a, b, Massana et al. 1994a, b). During the mixing period (from October to March) the entire water column is anoxic with sulfide, and only bacteria (heterotrophic and phototrophic) and anaerobic ciliates are found. During summer stratification (from April to September), a strong thermal gradient appears in the water column that isolates the hypolimnion (which remains rich in sulfide) from the epilimnion (which oxygenates completely). A dense community of organisms develops in the metalimnion along opposite gradients of oxygen and sulfide. This study is based on the information obtained on 19 sampling dates (3 to 12 depths sampled each date) during 1990 and 1991, with a total of 141 samples analyzed.

Determination of integrated biomass of the populations. Linear dimensions (length and width) of several individuals of each population were measured under the microscope with a graduated eyepiece (zooplankton, protozoans and algae) or by a digital image analysis system (bacteria). Individual volumes ( $\mathrm{mm}^{3}$ ind $^{-1}$ ) were calculated assuming simple geometrical shapes and converted to carbon content (pg $C$ ind.$^{-1}$ ) using conversion factors taken from the literature: $0.20 \mathrm{pg} \mathrm{C}$ $\mu \mathrm{m}^{-3}$ for bacteria (Bratbak 1993), $0.14 \mathrm{pg} \mathrm{C} \mu \mathrm{m}^{-3}$ for ciliates (Putt \& Stoecker 1989), and $0.15 \mathrm{pg} \mathrm{C} \mathrm{mm}^{-3}$ for algae (Strathmann 1967). For Thermocyclops dybowskii (aduits, copepodites and nauplii) we used an empirical regression between length $(L, \mu m)$ and dry weight (DW, pg): DW $=11 \times \mathrm{L}^{189}$ (Dumont et al. 1975). For the rotifers Polyarthra sp. and Kerateila sp., dry weights given in Stemberger \& Gilbert (1985) for rotifers of the same genera and size were assumed. Carbon content was considered to be $45 \%$ of dry weight. Dry weight was converted to volume considering that it is $19 \%$ of the wet weight (Bamstedt 1986) and has a density of $1 \mathrm{pg} \mathrm{mm}^{-3}$.

For each sampling date, several samples were taken at different depths, and the abundance (ind. $\mathrm{ml}^{-1}$ ) of the most important populations was determined. Integrated abundance (ind. $\mathrm{cm}^{-2}$ ) was calculated in a water column from 0 to $500 \mathrm{~cm}$ depth (see Eq. 1 in Massana \& Pedrós-Alió 1994a). Integrated biomass ( $\mu \mathrm{g} \mathrm{C} \mathrm{cm}^{-2}$ ) was obtained by multiplying integrated abundance times the carbon content.

Determination of trophic roles. Photosynthetic organisms were identified by the presence of pigments through phase contrast and epifluorescence microscopy. In addition, in order to identify the autotrophic populations in a broader sense, also including chemolithoautotrophic bacteria, natural samples were incubated for $4 \mathrm{~h}$ with radioactive bicarbonate $\left(\mathrm{NaH}^{14} \mathrm{CO}_{3}\right)$ and organisms were then examined directly by microautoradiography (details of the methods in GarcíaCantizano 1992)

The food spectrum of each phagotrophic organism was determined using 3 sources of information. First, a literature search was done looking for the grazing habits of these or similar organisms. Second, the morphology and autofluorescence of the material ingested by the phagotrophs was examined under the microscope. Chlorophyll a gives red autofluorescence when irradiated with blue light, and phycobilins, present in cryptomonads and cyanobacteria, give a strong red autofluorescence when irradiated with green light (Craig 1987). Third, in situ experiments of incorporation of fluorescent particles were performed on 
selected dates. Two bacterial suspensions, stained with FITC according to Sherr et al. (1987), were used: FLB (fluorescently labeled bacteria; dimensions of $1.1 \times$ $0.8 \mu \mathrm{m}$; volume $0.42 \mu^{3}$ ) and FLC (fluorescently labeled Chromatium; dimensions of $3.2 \times 1.4 \mu \mathrm{m}$; volume $4.2 \mu^{3}$ ). We also used 2 suspensions of fluorescent latex beads: SL (small latex; $0.49 \mu \mathrm{m}$ diameter; volume $0.06 \mu^{3}$ ) and LL (large latex; $2.44 \mu \mathrm{m}$ diameter; volume $7.6 \mu^{3}$ ). These particles were added to natural samples as tracers of colorless bacteria (FLB and SL) or phototrophic bacteria (FLC and LL). After a short incubation time, samples were fixed with formaldehyde and ingested particles inside predators were observed by epifluorescence microscopy. Uptake rates were measured counting the ingested particles at different times, and clearance rates ( $\mu$ ind ${ }^{-1} \mathrm{~h}^{-1}$ ) were calculated from uptake rates and particle concentrations.

Quantification of trophic fluxes. The integrated predation (prey eaten $\mathrm{cm}^{-2} \mathrm{~h}^{-1}$ ) of each single prey-predator relationship was computed from vertical profiles of abundance of prey and predator populations and the functional response of the predator, using an algorithm described in Massana \& Pedrós-Alió (1994a). Two parameters defined the functional response: the maximal uptake rate $\left(U_{\mathrm{m}}, \mu \mathrm{m}^{3}\right.$ ind $\left.\mathrm{d}^{-1} \mathrm{~h}^{-1}\right)$ and the half-saturation constant for ingestion $\left(k, \mu \mathrm{m}^{3} \mathrm{ml}^{-1}\right)$. These parameters have been extracted from the literature for each predator (Table 1). The functional response of Thermocyclops dybowskii was assumed to be the same as that of Tropocyclops prasinus mexicanus (Adrian \& Frost 1992). For Polyarthra sp. and Keratella sp. we used the functional response described for Brachionus rubens
(Rothhaupt 1990), modifying $U_{\mathrm{m}}$ to represent in both cases around $18 \%$ of the individual volume ingested per hour, as it is in $B$. rubens. The functional responses of Anuraeopsis fissa and Coleps sp. have been described previously (Massana \& Pedrós-Alió 1994a, Pedrós-Alió et al. 1995). The functional response of Prorodon sp. was considered to be similar to that of Coleps sp., but modifying $U_{m}$ to obtain the same $U_{m} / V$ ratio. For bacterivorous ciliates (and nauplii), we used the data presented in Fenchel (1980), relating maximal uptake rates with the size of ciliates and half-saturation constants with the size of ingested particles. To obtain the values of $U_{\mathrm{m}}$ and $k$ corresponding to each prey organism $\left(U_{\mathrm{m}}\right.$, prey eaten ind ${ }^{-1} \mathrm{~h}^{-1} ; k$, prey $\left.\mathrm{ml}^{-1}\right)$, the values of these 2 parameters expressed in biovolume (as they are shown in Table 1) are divided by the individual volume of the prey. Therefore, we assumed the functional response to be identical (in terms of total biovolume ingested) for each prey considered. We will discuss the significance and reliability of all these assumptions.

\section{RESULTS}

\section{Components of the food web: biomass and seasonal changes}

Dimensions, individual volume and carbon content of the most important organisms found in Lake Cisó during the years 1990 and 1991 are shown in Table 2. We considered all populations which composed at least $0.5 \%$ of the total biomass at some time. Crus-

Table 1 Parameters of the functional response of each predator used in this study. $U_{\mathrm{m}}$ : maximal uptake rate; $k$ : half-saturation constant: $V$ : individual volume $\left(\mu \mathrm{m}^{3}\right.$ ind.$\left.^{-1}\right) ; F_{\mathrm{m}}$ : maximal clearance rate $\left(U_{\mathrm{m}} / \mathrm{k}\right)$

\begin{tabular}{|c|c|c|c|c|c|}
\hline Organism & $\frac{U_{\mathrm{m}}}{\left(\mu \mathrm{m}^{3} \text { ind }^{-1} \mathrm{~h}^{-1}\right)}$ & $\begin{array}{c}k \\
\left(10^{6} \mu \mathrm{m}^{3} \mathrm{ml}^{-1}\right)\end{array}$ & $\begin{array}{c}U_{\mathrm{m}} / V \\
\left(\% \mathrm{~h}^{-1}\right)\end{array}$ & $\begin{array}{c}F_{\mathrm{m}} \\
\left(\mu \mathrm{l} \text { ind }^{-1} \mathrm{~h}^{-1}\right)\end{array}$ & Source \\
\hline \multicolumn{6}{|l|}{ Crustaceans } \\
\hline Thermocyclops dybowskii & 333000 & 16.5 & 9.4 & 20 & Adrian \& Frost (1992) \\
\hline Nauplii & 40000 & 50 & 11.5 & 0.80 & Fenchel (1980) \\
\hline \multicolumn{6}{|l|}{ Rotifers } \\
\hline Polyarthra sp. & 37000 & 6.7 & 17.6 & 5.5 & Rothhaupt (1990) \\
\hline Keratella sp. & 19000 & 6.7 & 18.1 & 2.8 & Rothhaupt (1990) \\
\hline Anuraeopsis fissa & 15400 & 20 & 24.3 & 0.77 & Massana \& Pedrós-Alió (1994a) \\
\hline \multicolumn{6}{|l|}{ Ciliates } \\
\hline Coleps sp. & 495 & 0.73 & 3.4 & 0.68 & Massana \& Pedrós-Alió (1994a) \\
\hline Prorodon sp. & 1600 & 0.73 & 3.4 & 2.2 & Massana \& Pedrós-Alió (1994a) \\
\hline Cyclidium sp. & 3200 & 50 & 40.1 & 0.064 & Fenchel (1980) \\
\hline Paramecium sp. & 14590 & 50 & 22.5 & 0.29 & Fenchel (1980) \\
\hline Vorticella sp. & 10690 & 50 & 25.0 & 0.21 & Fenchel (1980) \\
\hline Strombidium sp. & 2060 & 50 & 45.0 & 0.041 & Fenchel (1980) \\
\hline
\end{tabular}


Table 2. Dimensions (length and width), individual volume and carbon content of the main organisms in Lake Cisó. Contribution of each population to total biomass during summer stratification (12 sampling dates during 1990 and 1991) is also shown. HNF: heterotrophic nanoflaqellates

\begin{tabular}{|c|c|c|c|c|c|}
\hline \multirow{2}{*}{$\begin{array}{l}\text { Organism } \\
\text { Crustaceans }\end{array}$} & \multirow[t]{2}{*}{$\begin{array}{c}\text { Dimensions } \\
(\mu \mathrm{m})\end{array}$} & \multirow[t]{2}{*}{$\begin{array}{c}\text { Volume } \\
\left(\mu \mathrm{m}^{3} \text { ind } .^{-1}\right)\end{array}$} & $\begin{array}{l}\text { Carbon content } \\
\left(\mathrm{pg} C \text { ind } .^{-1}\right)\end{array}$ & \multicolumn{2}{|c|}{$\%$ summer biomass } \\
\hline & & & & & \\
\hline T dybowskii & $340 \times 70$ & 3520000 & 301000 & 0.24 & $0.00-1.30$ \\
\hline Nauplii & $100 \times 75$ & 349000 & 30000 & 0.15 & $0.00-0.63$ \\
\hline \multicolumn{6}{|l|}{ Rotifers } \\
\hline Polyarthra sp. & $95 \times 65$ & 211000 & 18000 & 0.63 & $0.00-2.42$ \\
\hline Keratella sp. & $100 \times 50$ & 105000 & 9000 & 0.16 & $0.00-1.80$ \\
\hline Anuraeopsis fissa & $77 \times 40$ & 63250 & 5410 & 1.88 & $0.00-6.77$ \\
\hline \multicolumn{6}{|l|}{ Ciliates } \\
\hline Coleps sp. & $42 \times 23$ & 14700 & 2060 & 5.48 & $0.00-19.05$ \\
\hline Prorodon sp. & $53 \times 30$ & 47600 & 6660 & 10.78 & $000-26.45$ \\
\hline Cyclidium sp. & $31 \times 21$ & 8000 & 1120 & 0.95 & $0.05-6.25$ \\
\hline Paramecium sp. & $108 \times 48$ & 64800 & 9080 & 0.68 & $0.00-5.28$ \\
\hline Vorticella sp. & $44 \times 43$ & 42750 & 5990 & 0.79 & $0.00-4.42$ \\
\hline Strombidium sp. & $21 \times 21$ & 4580 & 640 & 0.17 & $0.00-0.74$ \\
\hline HNF & $4 \times 4$ & 34 & 4.7 & 0.19 & $0.04-0.59$ \\
\hline \multicolumn{6}{|l|}{ Phytoplankton } \\
\hline C. phaseolus & $16 \times 10$ & 570 & 84 & 31.88 & $14.00-56.54$ \\
\hline Other algae & $6 \times 6$ & 115 & 21 & 5.24 & $0.00-15.77$ \\
\hline \multicolumn{6}{|l|}{ Bacterioplankton } \\
\hline Colorless bacteria & $0.95 \times 0.45$ & 0.13 & 0.026 & 26.51 & $10.41-48.20$ \\
\hline Chromatium sp. & $5.0 \times 2.7$ & 23.5 & 4.7 & 5.64 & $0.00-25.61$ \\
\hline Amoebobacter sp. & $2.0 \times 1.8$ & 3.6 & 0.71 & 8.49 & $2.68-19.36$ \\
\hline
\end{tabular}

were morphologically recognized and counted separately. The remaining bacteria, mostly typical-looking cocci and rods, were called 'colorless bacteria' The only significant planktonic organisms present in Lake Cisó and not included in Table 2 were anaerobic ciliates. These were the object of a separate study (Massana \& Pedrós-Alió 1994b).

Populations stratified at different depths of the water column. In a typical summer date (Fig. 1), there was a strong thermocline and most organisms accumulated at the metalimnion, in a narrow region where sulfide coexist.s with low concentrations of oxygen (Gasol et al. 1991a). There was a slight vertical segregation: in general the peak of phototrophic bacteria was placed below the peak of Cryptomonas, and the latter was found below the peak of algivorous ciliates and Anuraeopsis fissa. As we will see, such vertical distribution of populations and the presence of taceans, rotifers and ciliates were identified to genus or species level, whereas heterotrophic namoflagellates (HNF) and algae other than Cryptomonas lother algae, with different species each sampling date) were pooled together. Two bacterial species, the phototrophic purple bacteria Chromatium (probably $C$. minus) and Amoebobacter (probably A. purpureus), sulfide have strong implications for the flow of organic carbon through the food web.

We studied the changes in the integrated biomass of these populations for $2 \mathrm{yr}$ (Fig. 2). Crustaceans (Fig. 2A), rotifers (Fig. 2B), algivorous protozoans (Fig. 2C) and bacterivorous protozoans (Fig. 2D) were found only during summer stratification (shaded region

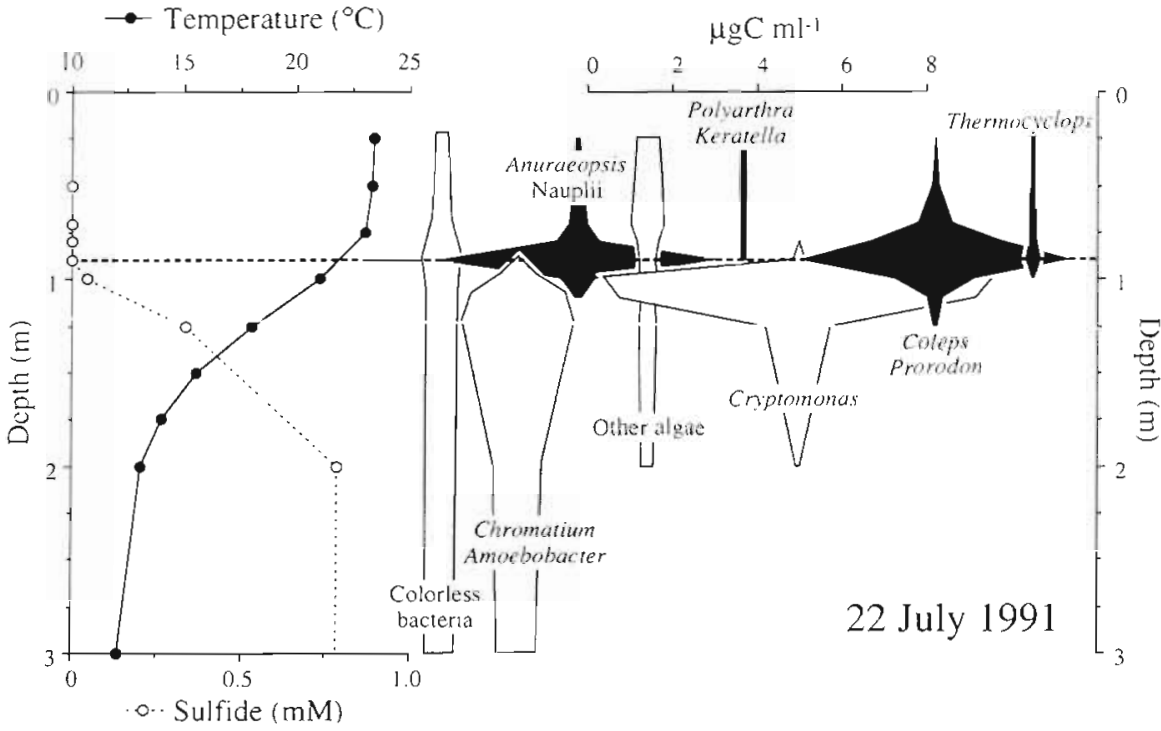

Fig. 1 Vertical profile of temperature and sulfide, and vertical distribution of the most significant populations in Lake Cisó on 22 July 1991. Black and gray kites indicate phagotrophic and osmotrophic groups, respectively. Horizontal dashed line: depth at which sulfide furst appears 

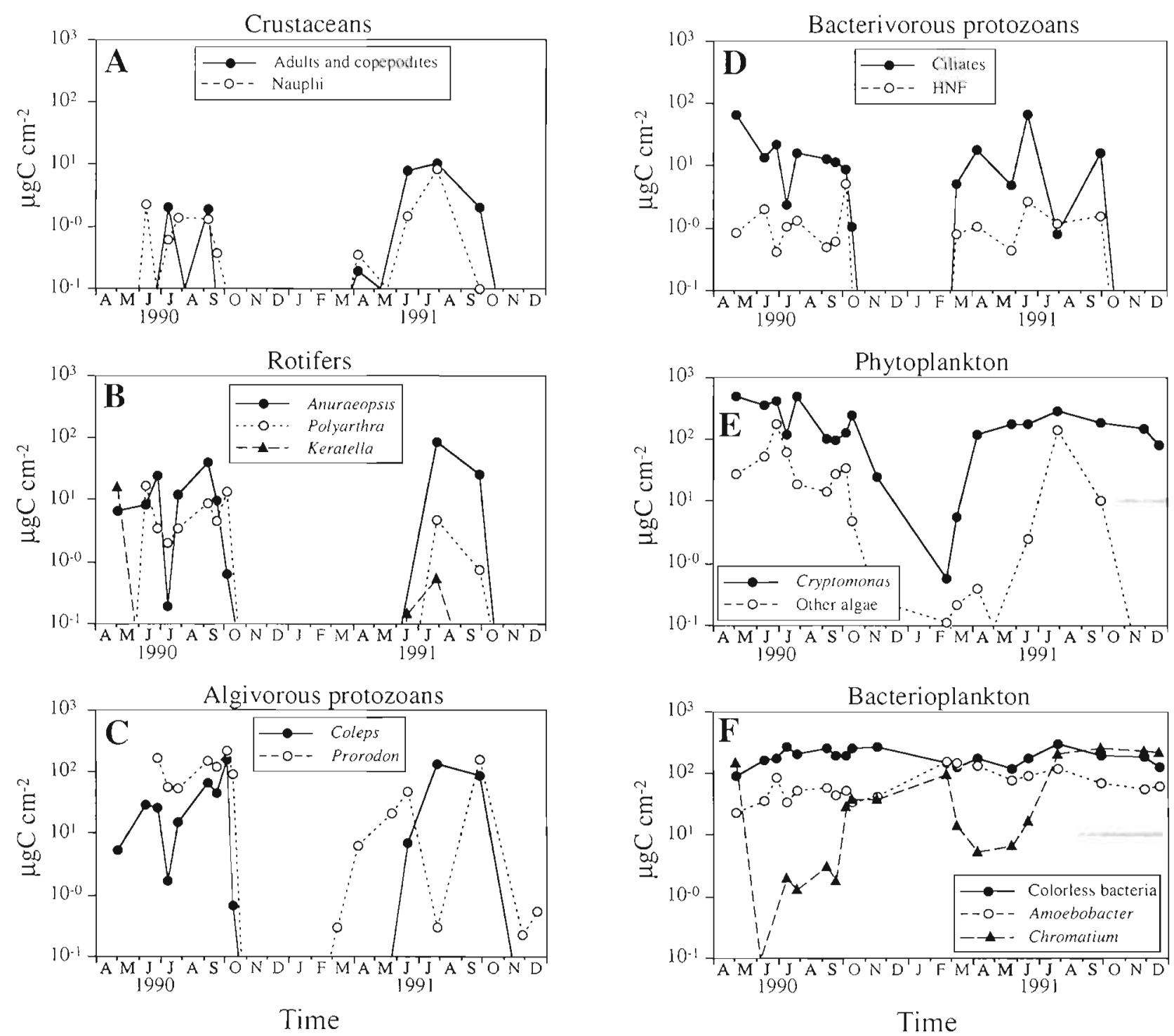

Fig. 2. Seasonal changes in integrated biomass of (A) crustaceans, (B) rotifers, (C) algivorous protozoans, (D) bacterivorous protozoans, (E) phytoplankton and (F) bacterioplankton in Lake Cisó from April 1990 to December 1991. Shaded region on the $X$-axis: stratification period (April to September). Horizontal line at $10 \mu \mathrm{g} \mathrm{C} \mathrm{cm}{ }^{-2}$ included to facilitate comparisons

in the horizontal axis) and disappeared during winter mixing Phytoplankton organisms (Fig. 2E) decreased during the mixing period to very low numbers, and all bacterial groups (Fig. 2F) were always present at a relatively constant biomass. The same populations that had disappeared during the mixing period developed during the summer of the second year, reaching similar biomass. This suggests the existence of a characteristic community that develops regularly every spring, changes very slightly during summer, and disappears with the fall mixing, when sulfide appears throughout the water column. A few populations dominated this summer community (Table 2): Cryptomonas, Prorodon, Coleps, Amoebobacter, Chromatium and colorless bacteria accounted for $90 \%$ of the total biomass.

\section{Trophic roles and functional groups: binary food web}

The trophic role of each significant population in the lake was determined by different approaches. Phototrophic bacteria, phytoplankton and some colorless bacteria incorporated inorganic carbon, as visualized by microautoradiography (data not shown, GarcíaCantizano 1992). The Chlorella cells endosymbiont in the ciliates Coleps and Prorodon also incorporated inorganic carbon, although their contribution to the growth of the ciliates (Massana unpubl. results) and to total primary production (García-Cantizano 1992) appeared to be insignificant. The food spectrum of phagotrophic organisms was determined by observa- 
tion of ingested material in natural or experimental samples (Table 3).

Populations with similar trophic habits were aggregated into functional groups, guilds or 'trophic species', an assemblage of organisms that eat the same food items and are eaten by the same predators (Cohen 1989, Pimm et al. 1991, Gaedke 1995). The community of Lake Cisó was aggregated into 8 functional groups. Thermocyclops dybowskii constituted the first functional group. This is a small cyclopoid copepod, a typical inhabitant of small bodies of water (Maier 1990), a raptorial feeder specialized in particles of the size of rotifers, ciliates and algae (Nilssen 1978). The second functional group included the algivorous rotifers Polyarthra and Keratella, which feed preferentially on Cryptomonas, although they can also ingest other algae (Bogdan \& Gilbert 1982). The third functional group was formed by the algivorous ciliates Coleps and Prorodon, that feed on Cryptomonas but never on bacteria or other algae. Such a selective predation behavior has also been observed by other investigators (Klaveness 1984. Finlay et al. 1991). The fourth group included the organisms feeding on the microbial component of the community, bacteria and other algae, and were named microphagous. The rotifer Anuraeopsis fissa dominated this assemblage, composed also of nauplii and the ciliates Vorticella, Paramecium, Cyclidium and Strombidium. Clearance rates of these organisms have been determined in situ (Table 3). The 4 remaining functional groups were not phagotrophic but osmotrophic. Three of them were phototrophic: Cryptomonas, other algae and phototrophic bacteria (Chromatium and Amoebobacter). The last group comprised the colorless bacteria, with a regular morphology but heterogeneous metabolism: heterotrophy, anoxygenic photosynthesis and chemolithoautotrophy.

Determination of the trophic role of the significant populations resulted in the binary food web, a qualitative diagram that shows the trophic links connecting the different compartments and gives information about the structure of the food web. Several standard parameters have been described to compare binary food webs. These parameters worc calculated in Lake Cisó (Table 4), both considering the unaggregated community formed by the 16 populations or assembjages presented in Table 2 (excluding Hî̀F), or the community aggregated into the 8 previously described functional groups. The values obtained are in good concordance with those found in other systems (Table 4). The increase of the fraction of top-basal links and the lack of the intermediate-intermediate links is a typical trait of the smallest webs (Havens 1992). The very short maximal length is also expected in such a system with a reduced spatial dimensionality (Briand \& Cohen 1987), where most populations grow at the same depth of the lake.

Table 3. Observation of the ingestıon of different prey by phagotrophic organisms in Lake Cisó. Numbers correspond to clearance rates determined in situ $\left(\mu \mathrm{l}\right.$ ind. $\left.{ }^{-1} \mathrm{~h}^{-1}\right)$. +: microscopic evidence of ingestion; -: microscopic evidence of non-ingestion. $[+],[-]$ : information taken from the literature. All other numbers and signs are from our observations. FLB: fluorescently labeled bacteria; SL: small latex; FLC: fluorescently labeled Chromatium; LL: large latex; HNF: heterotrophic nanoflagellates

\begin{tabular}{|c|c|c|c|c|c|c|c|}
\hline $\begin{array}{l}\text { Phagotrophic } \\
\text { organism }\end{array}$ & FLB & SL & \multicolumn{3}{|c|}{ Particles ingested } & Cryptomonas & Source \\
\hline \multicolumn{8}{|l|}{ Crustaceans } \\
\hline T. dybowskii & - & - & - & - & {$[+]$} & {$[+]$} & Adrian \& Frost (1992), Nilssen (1978) \\
\hline Nauplii & {$[+]$} & $1+1$ & + & 5.4 & + & {$[-1$} & Nilssen (1978) \\
\hline \multicolumn{8}{|l|}{ Rotifers } \\
\hline Polyarthrasp. & - & - & - & - & + & + & Bogdan \& Gilbert (1982) \\
\hline Keratella sp. & {$[+]$} & {$[+]$} & {$[+]$} & $1+1$ & {$[+]$} & {$[+]$} & $\begin{array}{l}\text { Bogdan \& Gilbert (1982), Ooms-Wilms } \\
\text { (1991) }\end{array}$ \\
\hline Anuraeopsis fissa & 0.02 & 0.05 & 0.52 & 0.06 & + & - & Ooms-Wilms (1991), Wilms et al. (1991) \\
\hline \multicolumn{8}{|l|}{ Ciliates } \\
\hline Colepssp. & -- & - & - & - & - & + & $\begin{array}{l}\text { Klaveness (1984), Finlay et al. (1988, } \\
\text { 1991), Madoni et al. (1990) }\end{array}$ \\
\hline Prorodon sp. & - & - & - & - & - & + & Finlay et al. (1988) \\
\hline Cyclidium sp. & 0.02 & + & 0.02 & + & - & - & Fenchel (1980), Finlay et al. (1988) \\
\hline Paramecium sp. & + & 0.02 & 0.35 & 0.24 & + & - & Fenchel (1980) \\
\hline Vorticella $\mathrm{sp}$ & 0.11 & 0.06 & 0.94 & 1.47 & + & - & Finlay et al. (1988) \\
\hline Strombidium $\mathrm{sp}$. & 0.04 & + & 0.42 & + & + & - & Finlay et al. (1988) \\
\hline HNF & 0.0003 & + & - & - & - & - & Fenchel (1986) \\
\hline
\end{tabular}


Table 4. Standard parameters of the binary food web of Lake Cisó. S: number of species (or functional groups); L: number of links; d: linkage density (L/S); TF, IF and BF: fractions of top, intermediate and basal species, respectively; Lti/L, Ltb/L, Lii/L and Lib/L: fractions of top-intermediate, top-basal, intermediate-intermediate and intermediate-basal links, respectively. Mean values reported in 2 comparative studies with unaggregated (Havens 1992) and aggregated (Cohen \& Briand 1984) binary food webs are also shown for comparison

\begin{tabular}{|c|c|c|c|c|c|c|c|c|c|c|}
\hline System & $S$ & $\mathrm{~L}$ & d & TF & IF & $\mathrm{BF}$ & $\mathrm{Lt} 1 / \mathrm{L}$ & $\mathrm{Ltb} / \mathrm{L}$ & $\mathrm{Lii} / \mathrm{L}$ & $\mathrm{Lib} / \mathrm{L}$ \\
\hline \multicolumn{11}{|l|}{ Lake Cisó } \\
\hline Unaggregated & 16 & 41 & 2.56 & 0.06 & 0.62 & 0.32 & 0.24 & 0.05 & 0 & 0.71 \\
\hline Aggregated & 8 & 11 & 1.37 & 0.13 & 0.37 & 0.50 & 0.27 & 0.18 & 0 & 0.55 \\
\hline \multicolumn{11}{|c|}{ Literature mean values } \\
\hline Unaggregated & - & - & - & 0.06 & 0.44 & 0.50 & 0.10 & 0.05 & 0.32 & 0.53 \\
\hline Aggregated & - & - & - & 0.19 & 0.53 & 0.29 & 0.35 & 0.08 & 0.30 & 0.27 \\
\hline
\end{tabular}

\section{Carbon fluxes among functional groups: trophic food web}

For each sampling date, we calculated the integrated biomass of each functional group and the carbon fluxes among them, considering only the links presented in Table 3. Since the community was similar during the entire summer, we averaged the values of biomass and fluxes calculated in 9 sampling days

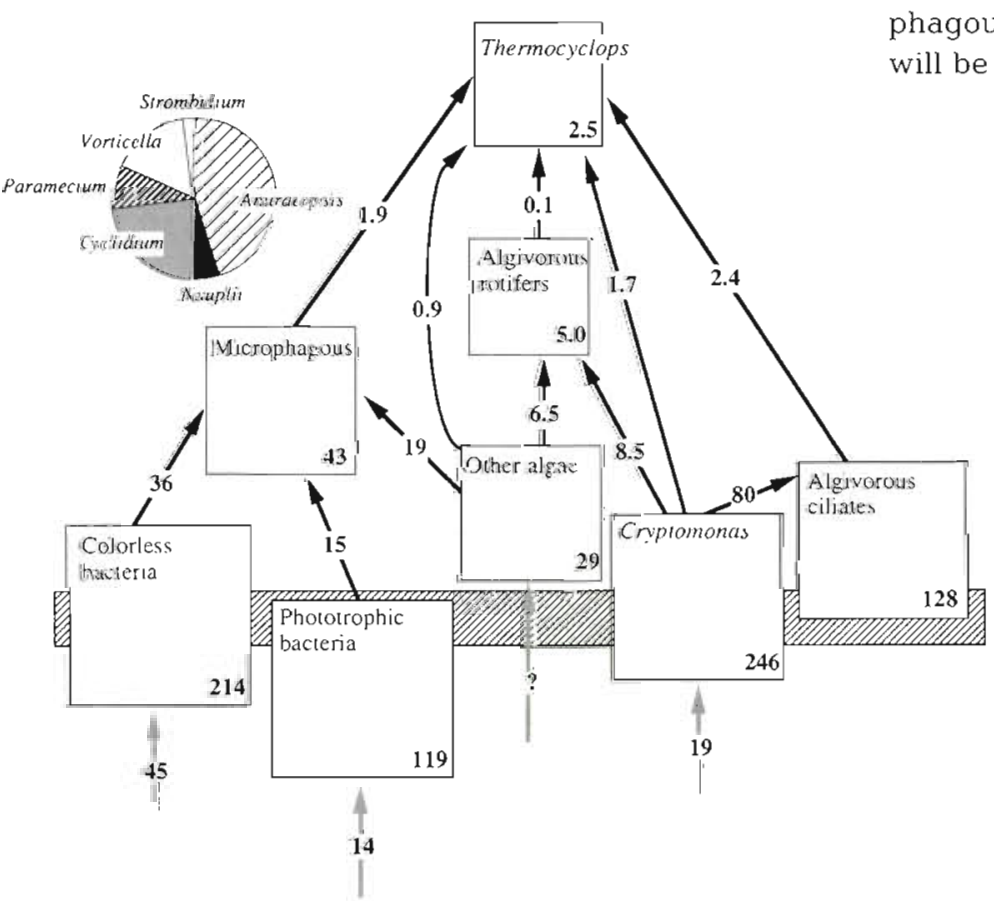

Fig. 3. Trophic food web in Lake Cisó obtained averaging the values of biomass and fluxes on 9 dates from summers 1990 and 1991. Biomass of compartments are shown inside boxes (in $\mu \mathrm{g} \mathrm{C} \mathrm{cm}^{-2}$ ) and fluxes are shown above arrows (in $\mu \mathrm{g} \mathrm{C} \mathrm{cm}^{-2} \mathrm{~d}^{-1}$ ). Compartments are drawn in a position relative to oxygen-sulfide interface (striped horizontal bar). Pie chart (left) shows the contribution of the different populations to total microphagous biomass. Average values during the stratification period of algal and bacterial production are also shown
(Fig. 3). As reference, the figure also shows the averaged value, during summer stratification, for primary production (García-Cantizano 1992) and for heterotrophic bacterial production (Calderón-Paz et al. 1993, García-Cantizano et al. 1994). The groups directly related with the sulfide interface (both bacterial groups, Cryptomonas and algivorous ciliates) show a large biomass and an apparent slow growth. In comparison, the biomass of Thermocyclops and algivorous rotifers is 1 or 2 orders of magnitude lower. Some compartments, especially algivorous ciliates and microphagous organisms, are severely unbalanced. This ill be discussed later.

\section{DISCUSSION}

\section{Limitations of the study}

We repeatedly sampled Lake Cisó for $2 \mathrm{yr}$, accounting for both the vertical and seasonal distribution of populations. We determined which populations contributed significantly to the biomass of the summer community and what was their trophic role. Then, we quantified the carbon fluxes among populations. Whereas biomass and trophic roles are likely well determined, the quantification of carbon fluxes has a degree of uncertainty, especially due to the use of the functional response of predators. The parameters defining this response, $U_{\mathrm{rn}}$ and $k$, were found independently and might not represent in situ conditions in Lake Cisó. In general, however, maximal clearance rates $\left(F_{m}\right.$ : Table 1$)$ were in the same range than in situ clearance rates (Table 3). The same values of $U_{\mathrm{m}}$ and $k$ (in $\mu \mathrm{m}^{3}$ ) were applied to each prey, assuming that predators were feeding on all prey 
with the same efficiency. In fact, predators normally have an optimal prey, depending on its size, shape, texture or behavior. Moreover, most organisms developed in depths with strong vertical gradients of temperature, oxygen and sulfide, which could cause changes of $U_{\mathrm{m}}$ and $k$ with depth. For these reasons, the values of carbon fluxes obtained (Fig. 3) must be viewed as approximate estimates (likely overestimates), with a certain degree of variability associated This exercise, however, remains valuable since it reveals some major trends in the flow of organic carbon through the community.

\section{Analysis of the trophic food web of Lake Cisó}

With the information on biomass, trophic roles and carbon fluxes presented in Fig. 3, we built a simplified diagram of the food web showing its main properties (Fig. 4). The first property was the presence of some functional groups (dark circles in Fig. 4) with high biomass, which was relatively stable all summer (Fig. 2) and had low predation losses. The growth of both bacterial groups was balanced by predation losses, with doubling times of 4 and $6 \mathrm{~d}$ for colorless and phototrophic bacteria, respectively. Losses by bacterivorous anaerobes were insignificant (Massana \& Pedrós-Alió 1994 b). The other 2 slow-growing compartments, Cryptomonas and algivorous ciliates, appeared unbalanced. We think this is due to the predation by the ciliates on Cryptomonas being overestimated. Most of the coexistence between both groups occurred in sulfide containing waters (Fig. 1), where the ciliates are

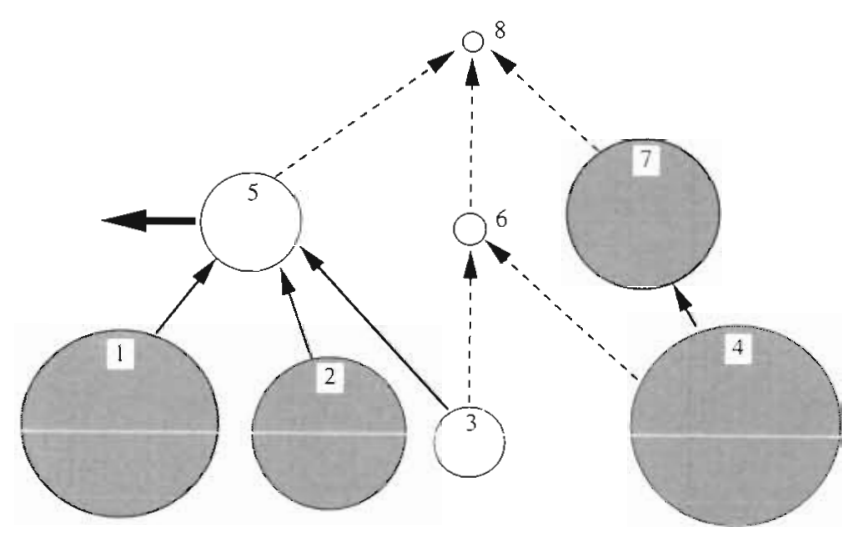

Fig. 4. Simplified diagram of the food web of Lake Cisó. Area of each compartment is proportional to its biomass. Dark compartments indicate slow growth and low predation losses. Dashed arrows: inefficient transfer of organic matter. Thick horizontal arrow: unknown mortality. 1. Colorless bacteria; 2: phototrophic bactena; 3: other algae; 4: Cryptomonas; 5 : microphagous organisms; 6 : algivorous rotifers; 7 : algivorous ciliates; 8 : Thermocyclops suboptimally adapted (Pedrós-Alió et al. 1995). Moreover, Cryptomonas migrated daily to spend the night in sulfide containing waters (Gasol et al. 1991a), thus reducing its preddtory lusses (Pedrós-Alió et al. 1995). To obtain balanced conditions that agree with observations of stable biomass, the predation by algivorous ciliates should be roughly equivalent to the growth of Cryptomonas, and this would result in doubling times of $9 \mathrm{~d}$ for Cryptomonas and $12 \mathrm{~d}$ for algivorous ciliates (40\% gross growth efficiency; Jonsson 1986).

The remaining groups (light circles in Fig. 4) presented different dynamics. A doubling time of $1 \mathrm{~d}$ was calculated for other algae assuming a growth to compensate predation losses. This assemblage seemed to have a fast growth, high predation losses and the typical succession of species throughout the summer (Sommer et al. 1986, Gasol \& Pedrós-Alió 1991). Microphagous organisms appeared unbalanced, with a potential fast growth (doubling time of $2 \mathrm{~d} ; 40 \%$ gross growth efficiency; Jonsson 1986), minor predation losses and stable biomass (Fig. 2). The predation calculated could be overestimated (due to a similar mechanism of prey refuge), and the replacement of populations, especially of ciliates, suggests unknown mortality factors. The 2 zooplankton compartments always show low biomass (see below).

The second property of the food web of Lake Cisó was the inefficient transfer of organic matter from lower trophic levels to zooplankton (dashed lines in Fig. 4). This can be deduced by analyzing the values of both biomass and carbon flux. Theoretical models of steadystate food chains suggest a rather similar biomass in consecutive trophic levels (Fenchel \& Finlay 1990). This seemed true for the pairs bacteria-microphagous organisms and Cryptomonas-algivorous ciliates, whereas the biomass of Thermocyclops was much lower. This indicated an efficient transfer of energy (although slow) between the first and the second trophic levels and an uncoupling between the second and the third. Data on carbon fluxes showed that Thermocyclops could ingest enough food to develop optimally in the lake. Despite the absence of predatory losses, its biomass always remained low, and its small size (Table 2 ) indicated that it was able to develop only to copepodite stages. Again, this suggests an inefficient transfer of organic matter to the highest levei of the system.

Both properties of the food web can be explained by the same reason: the presence of opposite gradients of oxygen and sulfide at the metalimnion and the differential adaptation of certain populations to thrive in such an environment, a compromise between suboptimal growth and a spatial refuge from predators. This was well exemplified by Cryptomonas, the aerobic organism better adapted to survive in sulfide waters: its large biomass grew slowly, with only a minor fraction 
being consumed by the ciliates Coleps and Prorodon These ciliates presented a similar trend: in the metalimnion they could escape from their predators, build a large biomass, and grow slowly by feeding on Cryptomonas. Phototrophic bacteria were truly anaerobes and their large biomass was due to the same mechanism, predation refuge. The zooplankton of Lake Cisó was not able to consume efficiently the metalimnetic biomass, likely because they do not tolerate sulfide at all. Moreover, we had the chance to follow the invasion of a new predator in Lake Cisó during summer 1992, Daphnia pulex, which was better adapted than Thermocyclops to microoxic waters (Massana et al. 1994a). D. pulex consumed most aerobic organisms (Cryptomonas, algivorous ciliates, microphagous organisms) and reached a huge biomass, indicating an efficient transfer of organic matter from the metalimnetic community to the epilimnetic zooplankton. Again, the populations better adapted to sulfide waters, such as phototrophic bacteria, escaped predation.

\section{General implications of our study}

Many properties of the food web of Lake Ciso differ from what is known from other freshwater or marine systems. First, most of the biomass is formed by a few populations, resulting in a very low diversity. Second, there is a dramatic vertical heterogeneity, with most of the biomass accumulated at the metalimnion and existence of spatial refuges for prey. Third, the turnover time of most of the metalimnetic biomass is long, with slow growth and low predation losses. Fourth, there is a lack of seasonal succession, unlike in many lakes of the temperate region (Sommer et al. 1986). This has been interpreted as a result of the absence of the forces driving succession, i.e. competition and predation (Gasol \& Pedrós-Alió 1991, Massana et al. 1994b). Fifth, the bacterial component is very important: it represents $40 \%$ of the biomass of the system (Table 2), and total bacterial production is always higher than algal production (Fig. 3). The microbial loop, regarded as the routing of organic carbon from algae to protozoans through heterotrophic bacteria, is only a part of this bacteria-based food web, since the heterotrophic bacterial production also depends on imported organic matter (likely from leaves of the surrounding trees) and there is an important contribution of autotrophic bacterial production. Contrary to what has been described in most aquatic systems (Fenchel 1986), bacterivory is performed by ciliates and rotifers, and heterotrophic nanoflagellates are never significant in terms of biomass (Table 2, Fig. 2D).

The characteristics of the community of Lake Cisó allow a description of its food web with a detail that is normally impossible in other systems (Pomeroy 1991). Since the data derive from several samplings during the summer period it is more than an instantaneous description of the food web (Pimm et al. 1991). The binary food web is similar to that found in other communities (Table 4), suggesting that general ecological theory also applies in systems dominated by microorganisms and with a strong spatial heterogeneity. The finding of an inefficient transfer of organic matter from the metalimnetic biomass to the epilimnetic zooplankton can be applied to other systems with similar properties, such as thermally stratified or meromictic lakes with anoxic deep water and biomass accumulation in the oxicanoxic interface. Metalimnetic communities can be regarded as systems with large and slow-growing biomass, with a minor fraction of the biomass channeled to epilimnetic zooplankton. The presence of sulfide seems to be the key factor, providing a refuge from predation.

Acknowledgements. This work was supported by DClCYT grant PB91-0075 to C.P.A. R.M. and J.G.C. were recipients of scholarships from the Spanish Ministry of Education and Science. We are thankful to Juan I. Calderón-Paz for sharing data and to Josep M. Gasol for helpful comments. We also thank Emilio Ortega for help during sampling and data measurements

\section{LITERATURE CITED}

Adrian R, Frost TM (1992) Comparative feeding ecology of Tropocyclops prasinus mexicanus (Copepoda, Cyclopoida). J Plankton Res 14:1369-1382

Arvola L, Salonen K, Kankaala P, Lehtovaara A (1992) Vertical distributions of bacteria and algae in a steeply stratified humic lake under high grazing pressure from Daphnia longispina. Hydrobiologia 229:253-269

Baker AL, Baker KK, Tyler PA (1985) Fine-layer depth relationships of lakewater chemistry, planktonic algae and photosynthetic bacteria in meromictic Lake Fidler, Tasmania. Freshwater Biol 15:735-747

Båmstedt U (1986) Chemical composition and energy content. In: Corner EDS, O'Hara SCM (eds) The biological chemistry of marine copepods. Clarendon Press, Oxford, p 1-58

Bogdan KG, Gilbert JJ (1982) Seasonal patterns of feeding by natural populations of Keratella, Polyarthra and Bosmina: clearance rates, selectivities, and contributions to community grazing. Limnol Oceanogr 27:918-934

Bratbak G (1993) Microscope methods for measuring bacterial biovolume: epifluorescence microscopy, scanning electron microscopy, and transmission electron microscopy. In Kemp PF, Sherr BF, Sherr EB, Cole JJ (eds) Handbook of methods in aquatic microbial ecology. Lewis Publishers, Boca Raton, p 309-317

Briand F, Cohen JE (1987) Environmental correlates of food chain length. Science 238:956-960

Calderón-Paz JI, García-Cantizano J, Vaqué D, Pedrós-Alió C (1993) Heterotrophic bacterial production in systems of the northern Spanish Mediterranean region. Verh lnt Verein Limnol 25:739-742

Cohen JE (1989) Food webs and community structure. In Roughgarden J, May RM, Levin SA (eds) Perspectives in ecological theory. Princeton University Press, Princeton NJ, p $181-202$ 
Cohen JE, Briand F (1984) Trophic links of community food webs. Proc Natl Acad Sci USA 81:4105-4109

Craig SR (1987) The distribution and contribution of picoplankton to deep photosynthetic layers in some meromictic lakes. Act.d Acad Abo Ser B Math Phys Mat Naturvetensk Tek 47:55-81

Dumont HJ, Van de Velde I, Dumont S (1975) The dry weight estumate of biomass in a selection of cladocera, copepoda and rotifera from the plankton, periphyton and benthos of continental waters. Oecologia 19:75-97

Fenchel T (1980) Suspension feeding in ciliated protozoa feeding rates and their ecological significance. Microb Ecol 6:13-25

Fenchel T (1986) The ecology of heterotrophic microflagellates. Adv Microb Ecol 9:57-97

Fenchel T, Finlay BJ (1990) Anaerobic free-living protozoa: growth efficiencies and the structure of anaerobic communities. FEMS Microbiol Ecol 74:269-276

Finlay BJ, Clarke KJ, Cowling AJ, Hindle RM, Rogerson A, Berninger UG (1988) On the abundance and distribution of protozoa and their food in a productive freshwater pond. Eur J Protistol 23:205-217

Finlay BJ, Clarke KJ, Vicente E, Miracle MR (1991) Anaerobic ciliates from a sulphide-rich solution lake in Spain. Eur $J$ Protistol 27:148-159

Fry B (1986) Sources of carbon and sulfur nutrition for consumers in three meromictic lakes of New York State. Limnol Oceanogr 31:79-99

Gaedke U (1995) A comparison of whole-community and ecosystem approaches (biomass size distributions, food web analysis, network analysis, simulation models) to study the structure, function and regulation of pelagic food webs. J Plankton Res 17:1273-1305

García-Cantizano J (1992) Análisis funcional de la comunidad microbiana en ecosistemas planctónicos. PhD thesis, Universitat Autonoma de Barcelona

García-Cantizano J, Calderón-Paz JI. Pedrós-Alió C (1994) Thymidine incorporation in Lake Cisó: problems in est1mating bacterial secondary production across oxic-anoxic interfaces. FEMS Microbiol Ecol 14:53-64

Gasol JM, García-Cantizano J, Massana R, Peters F, Guerrero $R$, Pedrós-Alió C (1991a) Diel changes in the microstratification of the metalimnetic community in Lake Cisó. Hydrobiologia 211:227-240

Gasol JM, Guerrero R, Pedrós-Alió C (1991b) Seasonal variations in size structure and procaryotic dominance in sulfurous Lake Cisó. Limnol Oceanogr 36:860-872

Gasol JM, Pedrós-Alió C (1991) On the origin of deep algal maxima: the case of Lake Cisó. Verh Int Verein Limnol 24 $1024-1028$

Gasol JM, Peters F, Guerrero R, Pedrós-Alió C (1992) Community structure in Lake Cisó: biomass allocation to trophıc groups and differing patterns of seasonal succession in the meta- and epilimnion. Arch Hydrobiol 123:275-303

Havens K (1992) Scale and structure in natural food webs. Science 257:1107-1109

Jonsson PR (1986) Particle size selection, feeding rates and growth dynamics of marine planktonic oligotrichous ciliates (Ciliophora: Oligotrichina). Mar Ecol Prog Ser 33: $265-277$

Klaveness D (1.984) Studies on the morphology, food selection and growth of two planktonic freshwater strains of Coleps sp. Protistologica 20:335-349

Madoni P, Berman T, Hadas O, Pinkas R (1990) Food selection and growth of the planktonic cillate Coleps hirtus isolated from a monomictic subtropical lake. J Plankton Res 12: $735-741$
Maier G (1990) The seasonal dynamics of Thermocyclops dybowskii (Lande, 1890), in a small pond (Copepoda, Cyclopoida). Crustaceana 59:76-81

Mas J, Pedrós-Alió C, Guerrero R (1990) In situ specific loss and growth rates of purple sultur bacteria in Lake Ciso. FEMS Microbjol Ecol 73:271-281

Massana R, Gasol JM, Jürgens K, Pedrós-Alió C (1994a) Impact of Daphnia pulex on a melalimnetic microbial community. J Plankton Res 16:1379-1399

Massana R, Gasol JM, Pedrós-Alió C (1994b) Interrupted succession of ciliate communities in sharply stratified metalimnia. Mar Microb Food Webs 8:189-200

Massana $R$, Pedrós-Alió C (1994a) A method to determine integrated predation in stratified waters. Limnol Oceanogr 39:248-262

Massana R, Pedrós-Alió C (1994b) Role of anaerobic ciliates in planktonic food webs: abundance, feeding, and impact on bacteria in the field. Appl Environ Microbiol 60: $1325-1334$

Matsuyama M, Shicouzu E (1978) Importance of photosynthetic sulfur bacteria Chromatium sp. as an organic matter producer in Lake Kaiike. Jpn J Limnol 39:103-111

Mazumder A, Dickman MD (1989) Factors affecting the spatial and temporal distribution of phototrophic sulfur bacteria. Arch Hydrobiol 116:209-226

Nilssen JP (1978) On the evolution of life histories of limnetic cyclopoid copepods. Mem Ist Ital Idrobiol 36:193-214

Ooms-Wilms AL (1991) Ingestion of fluorescently labeled bacteria by rotifers and cladocerans in Lake Loosdrecht as measures of bacterivory: preliminary results. Mem Ist Ital Idrobiol 48:269-278

Pedrós-Alió C. Guerrero R (1993) Microbial ecology in Lake Cisó. Adv Microbial Ecol 13:155-209

Pedrós-Alió C, Massana R, Latasa M, García-Cantizano J, Gasol JM (1995) Predation by ciliates on metalimnetic Cryptomonas population: feeding rates, impact and effects of vertical migration. J Plankton Res 17:2131-2154

Pimm SL, Lawton JH, Cohen JE (1991) Food web patterns and their consequences. Nature 350:669-674

Pomeroy LR (1991) Relationships of primary and secondary production in lakes and marine ecosystems. In: Cole JJ, Lovett GM. Findlay SEG (eds) Comparative analyses of ecosystems. Springer-Verlag, New York, p 97-119

Putt M. Stoecker DK (1989) An experimentally determined carbon: volume ratio for marine 'oligotrichous' ciliates from estuarine and coastal waters. Limnol Oceanogr 34: $1097-1103$

Rothhaupt KO (1990) Changes of the functional responses of the rotifers Brachionus rubens and Brachionus calyciflorus with particles sizes. Limnol Oceanogr 35:24-32

Sherr BF, Sherr EB, Fallon RD (1987) Use of monodispersed, fluorescently labeled bacteria to estimate in situ protozoan bacterivory. Appl Environ Microbiol 53:958-965

Sommer U, Gliwicz ZM, Lampert W, Duncan A (1986) The PEG-model of seasonal succession of planktonic events in iresin waters. Arch Hydúvivi 100:433-47i

Sorokin Yul (1970) Interrelations between sulphur and carbon turnover in meromictic lakes. Arch Hydrobiol 66:391-446

Stemberger RS, Gilbert JJ (1985) Body size, food concentration, and population growth in planktonic rotifers. Ecology $66: 1151-1159$

Strathmann RR (1967) Estimating the organic carbon content of phytoplankton from cell volume or plasma volume. Limnol Oceanogr 12:411-418

Wilms AL, Gulati RD, Postema G (1991) First attempt to measure the clearance rate of Anuraeopsis fissa. Verh Int Verein Limnol 24:742-744 